\title{
Variation in host resistance and pathogen selective value in the interaction between Pinus sylvestris and the fungus Crumenulopsis sororia
}

\author{
RA Ennos and KC McConnell \\ School of Biological Sciences, University of Edinburgh, King's Buildings, Mayfield Rd, Edinburgh EH9 3JU, Scotland
}

\begin{abstract}
There have been many studies of plant pathogen evolution in systems showing gene-for-gene control of host resistance. However little is known about situations, exemplified by Scots pine, Pinus sylvestris, and its fungal pathogen Crumenulopsis sororia, where variation in host resistance is quantitative. In a field experiment genetically marked isolates of $C$. sororia from three natural populations were reciprocally inoculated on 1 - and 2-year-old branch tissue of $P$. sylvestris in the three sites from which they had been collected. Quantitative variation in host resistance was measured by comparing the performance of the same inocula on different host populations, individuals and tissues. The selective value of isolates derived from different populations was estimated by comparing the frequency of
\end{abstract}

genotypes in lesion re-isolations with those in the initial inoculum mixtures. Host resistance varied significantly among populations, individuals within populations and between 1- and 2-year-old branch tissue of $P$. sylvestris. Large differences in the relative selective values of $C$. sororia isolates from different populations were detected. The selective value of pathogens was independent of the host population on which they were inoculated. However, their selective value did depend on the age of the tissue on which they grew. The implications of these results for modelling evolution in pathogen-host interactions that lack gene-forgene determination of host resistance are discussed. Heredity (2003) 91, 193-201. doi:10.1038/sj.hdy.6800297

Keywords: pathogen evolution; reciprocal transplant; quantitative resistance; Pinus sylvestris; Crumenulopsis sororia

\section{Introduction}

Much empirical and theoretical work on plant-pathogen evolution deals with systems where there is 'gene-forgene' control of host resistance (Thompson and Burdon, 1992). If 'avirulence' alleles in the pathogen are matched by corresponding 'resistance' alleles in the plant, the pathogen is recognised and defensive responses are triggered, leading to host resistance. Where 'avirulence' alleles are not matched by corresponding 'resistance' alleles, there is no initiation of host defensive response and the host is susceptible to the pathogen (Flor, 1956; Parker, 1994).

Gene-for-gene interactions giving qualitative variation in host resistance are widespread in natural systems particularly those involving biotrophic pathogen (eg rusts and smuts) (Jarosz and Davelos, 1995). They are often associated with ecological situations in which pathogen populations fluctuate dramatically in size over both space and time and exhibit epidemic dynamics (Thrall and Burdon, 1997). There is now a well-developed body of theory that deals with evolution involving gene-for-gene interactions, and this has been applied to investigate the behaviour of a restricted number of

Correspondence: RA Ennos, School of Biological Sciences, University of Edinburgh, King's Buildings, Mayfield Rd, Edinburgh EH9 3JU, Scotland.E-mail:rennos@ed.ac.uk

Received 8 April 2002; accepted 25 February 2003 natural model systems (Burdon and Jarosz, 1991; Burdon and Thrall, 1999).

There are many plant-pathogen interactions, however, which do not exhibit these characteristics. For instance, many forest pathogens infecting roots, buds and shoots of trees are necrotrophs rather than biotrophs, killing host tissue before exploiting it (Manion, 1990). They commonly exist in permanent association with their hosts and exhibit endemic population dynamics. Within population, they are usually located on stressed tissues or individuals where the defence system of the host is less effective. Their success in invading host tissue is largely determined, not by whether they are recognised by their host (as assumed in a simple gene-for-gene system), but by their ability to overcome the host defence when it is initiated in response to the damage that they provoke (Schoenweiss, 1975). The outcome of pathogen attack can be thought of as a balance between pathogen 'aggressiveness' (ability to exploit host tissue) and host resistance. Both pathogen aggressiveness and host resistance are best treated as quantitative rather than qualitative characters (Kolmer and Leonard, 1986; De Nooij and van Damme, 1988a, b; Parlevliet, 1989).

Understanding pathogen evolution in these systems requires empirical information on the extent and distribution of quantitative variation for resistance within and among host populations. It needs to be recognised that in natural situations a large component of variation in host resistance is likely to be environmental rather than genetic in origin. This contention is supported by a 
body of observational and experimental evidence, indicating that the imposition of stress on host plants reduces their ability to mount defensive responses, decreases resistance and increases damage by necrotrophic pathogens (Schoenweiss, 1981)

Information on natural patterns of quantitative variability in host resistance can be obtained by artificial inoculation of different host populations, individuals and tissues using a defined pathogen inoculum. Measures of the relative success of this standard inoculum in the different host environments provide a way of quantifying variation in phenotypic host resistance, and investigating the scale over which resistance variation is perceived by the pathogen.

A second piece of information required for understanding necrotrophic pathogen evolution is whether pathogen genotypes differ in fitness over the range of environments provided by their hosts. This can be investigated by measuring the relative success of genetically marked pathogens when grown in mixture on a variety of host populations, individuals and tissues. Comparisons of pathogen genotype performance in these situations can be used to estimate their relative selective values using a range of established techniques (Ennos and McConnell, 1995).

Here we report the results of an experiment designed both to quantify patterns of phenotypic host resistance in the field, and to estimate the relative fitness of pathogen genotypes derived from different natural populations in a range of host environments. The experiment involved the necrotrophic canker pathogen Crumenulopsis sororia Groves, and its host Scots pine (Pinus sylvestris L.). Mixtures of genetically marked C. sororia isolates derived from three sites were inoculated on branch tissue of $P$. sylvestris of different ages in the pinewoods from which the pathogen had been collected.

To detect variation in host resistance, the frequency of infection, length of lesion and frequency of asexual reproduction were measured for the same inoculum growing on different host populations and host tissues. To estimate the selective values of pathogen genotypes inoculated in mixture, reproductively successful genotypes were re-isolated from induced cankers. The frequency of genetically marked individuals reisolated from the cankers was then compared with their frequency in the original inoculum to estimate their relative selective value.

\section{Methods}

\section{Study system}

Pathogen: C. sororia is an ascomycete fungus that invades small wounds and causes perennial cankers on shoots of its woody plant host, Scots pine, P. sylvestris (Batko and Pawsey, 1964). C. sororia is found throughout the natural range of $P$. sylvestris in Scotland. The pathogen is spread by means of wind-borne sexual ascospores released from apothecia that develop on the surface of cankers. Ascospores germinate in water on the bark surface of shoots of $P$. sylvestris and infection takes place via small wounds (Hayes and Manap Ahmed, 1975).

Growth and destruction of host shoot tissue by pathogen mycelium induces both the localised release of resin by the tree, reducing mycelial growth rate, and the development of an impermeable barrier which, if completed in time, walls off the infection (Batko and Pawsey, 1964). Infected tissue becomes suffused with a black pigment laid down by the pathogen, making it easy to detect the extent of pathogen spread. Following successful infection, the fungus produces asexual fruiting bodies, pycnidia, on the surface of the canker. These release asexual macroconidial spores that disperse along the branch in water films and spread the infection locally. At a later stage, sexual reproduction occurs through outcrossing between adjacent haploid mycelia in the canker leading to the development of apothecia (Ennos and Swales, 1987). Ascospores are released from apothecia under humid conditions.

Pathogen genetic structure: Previous investigations of C. sororia using genetic markers have established that the C. sororia individuals present in a native pinewood comprise a large number of multilocus genotypes (Ennos and Swales, 1987). These represent the products of random sexual outcrossing between genotypes. Asexual reproduction of individual genotypes is negligible, as shown by the absence of significant linkage disequilibrium between loci (Ennos and Swales, 1991a). Thus, within populations variation for genetic markers is essentially randomised on the genetic background. Further evidence on the structure of genetic diversity within populations comes from an analysis of quantitative traits (resistance to host-defensive chemicals). A high proportion of the variation for these traits is found between $C$. sororia families, indicating that the pairs of genotypes giving rise to different families are distinct (Ennos and Swales, 1991b).

In addition to these studies of genetic variation within C. sororia populations, the distribution of quantitative genetic variation among native populations has also been investigated. There is so far no evidence for significant genetic differentiation for important quantitative characters between $C$. sororia populations occupying different pinewoods in Scotland (Ennos and Swales, 1991b).

Host: P. sylvestris is the only pine native to Scotland where it is now found in approximately 40 remnant populations throughout its original range (Steven and Carlisle, 1959). The species is present in a diversity of habitats. These range from very oceanic sites in the west with rainfall levels of greater than $2000 \mathrm{~mm}$ per year and poor drainage, to sites in the east with more continental climates, rainfall levels of less than $800 \mathrm{~mm}$ per year and on freely draining soil. Although genetic marker differentiation is low among these populations, there is good evidence for significant genetic differentiation among populations for quantitative traits, including disease resistance (Ennos et al, 1997).

\section{Study populations}

Three native pinewood sites, Loch Maree (LM), Glen Affric (GA) and Abernethy (AB) were selected for study to encompass the diversity of environmental conditions and genotypes that exist within the range of $P$. sylvestris in Scotland (Steven and Carlisle, 1959). LM is located in the North-Western group of pinewoods in an area of high rainfall (2000 mm/year) and a very oceanic climate. GA lies in the Great Glen group of pinewoods with an 
intermediate rainfall level of $1780 \mathrm{~mm} /$ year. $A B$ is located to the east in the Speyside group of pinewoods where the climate is more continental in nature and rainfall is near $770 \mathrm{~mm}$ /year. A previous provenance/ progeny trial with seed material from these populations grown at a common site has established that they are genetically differentiated for ecologically important quantitative characters such as growth rate and date of spring bud burst (Ennos et al, 1997).

\section{Pathogen samples}

At each of the sites LM, GA and AB an apothecium of $C$. sororia was collected in summer 1989 from at least 10 trees of $P$. sylvestris. Five single ascospore isolates were obtained from each apothecium and grown on $1 \%$ malt extract agar (MEA; $33 \mathrm{~g}$ malt extract, 10 gagar/1). A sample of each isolate was then grown in liquid culture medium (LCM; $10 \mathrm{~g}$ glutamic acid, $10 \mathrm{~g}$ glucose, $2 \mathrm{~g}$ yeast extract, $1 \mathrm{~g} \mathrm{KH} \mathrm{KO}_{4}, 0.02 \mathrm{~g} \mathrm{MgSO}_{4} \cdot 7 \mathrm{H}_{2} \mathrm{O}, 0.02 \mathrm{~g} \mathrm{FeCl}$, $\left.880 \mu \mathrm{g} \mathrm{ZnSO}_{4} \cdot 7 \mathrm{H}_{2} \mathrm{O}, 400 \mu \mathrm{g} \mathrm{MnSO}_{4} \cdot 4 \mathrm{H}_{2} \mathrm{O} / \mathrm{l}\right)$ and scored for its genotype at the GOT isozyme locus. In this haploid fungus, individuals possess either the fast Got ${ }^{F}$ or slow Got $^{S}$ migrating allele (Ennos and Swales, 1987).

From each population, five individuals of genotype $\mathrm{Got}^{F}$ and five individuals of genotype $\mathrm{Got}^{S}$ were chosen at random for inclusion in inocula with the restriction that no two individuals came originally from the same apothecium. This sampling procedure ensures that each isolate used in the experiment represents the unique product of a sexual outcrossing event between different parent genotypes, and that within samples from the same population the marker alleles are randomised on the genetic background (see earlier).

\section{Preparation of inocula}

Three inocula $\left(\mathrm{I}_{1}, \mathrm{I}_{2}\right.$ and $\left.\mathrm{I}_{3}\right)$ were prepared, each containing a different 1:1 mixture of isolates from two of the three populations. Inocula were designed such that the origin of an isolate in the mixture could be determined from its isozyme genotype. The compositions of inocula were:

Inoculum $\mathrm{I}_{1}$ : Five unique $\mathrm{LM}$ isolates, all genotype $\mathrm{Got}^{F}+$ five unique AB isolates, all genotype $\mathrm{Got}^{S}$.

Inoculum $\mathrm{I}_{2}$ : Five unique $\mathrm{LM}$ isolates, all genotype $G o t^{S}+$ five unique GA isolates, all genotype $\operatorname{Got}^{F}$.

Inoculum $\mathrm{I}_{3}$ : Five unique GA isolates, all genotype $G o t^{S}+$ five unique AB isolates, all genotype $\mathrm{Got}^{F}$.

Mixed inocula $I_{1}, I_{2}$ and $I_{3}$ were produced by first growing individually on MEA plates each of the 30 genotyped isolates to be included in the experiment. After 2 weeks, a $7 \mathrm{~mm}$ diameter circle of agar plus mycelium was cut from the actively growing margins of one of the isolates and placed in $1.5 \mathrm{ml}$ sterile distilled water within a $20 \mathrm{~mm}$ diameter maceration tube. This isolate was thoroughly macerated, and the macerate added to a $20 \mathrm{ml}$ tube to form a component of the appropriate mixture, $\mathrm{I}_{1}, \mathrm{I}_{2}$ or $\mathrm{I}_{3}$. When all 10 macerated isolates had been added to create an inoculum mix, it was vortexed and $0.5 \mathrm{ml}$ aliquots were poured onto 10 fresh MEA plates and spread evenly. After incubation at $20^{\circ} \mathrm{C}$ for 2 weeks, these plates were used to inoculate trees in the reciprocal transplant experiment.
To assess the initial composition of isolates from different sources in the inocula additional $10^{-3}$ and $10^{-4}$ dilutions were made from the stocks of mixtures $I_{1}$, $\mathrm{I}_{2}$ and $\mathrm{I}_{3}$, and $0.5 \mathrm{ml}$ aliquots spread on MEA plates. After 5 days growth, individual colonies were identified under a binocular microscope, picked off the agar and transferred to sterile twigs of $P$. sylvestris. Once they had colonised, these twigs were frozen for storage at $-20^{\circ} \mathrm{C}$. These isolates were later grown up in liquid medium and scored for their Got genotype to determine the original population composition of the inoculum mixtures.

\section{Artificial inoculations}

At each of the three sites a permanent quadrat measuring between $30 \mathrm{~m} \times 20 \mathrm{~m}$ and $30 \mathrm{~m} \times 30 \mathrm{~m}$ (depending on tree density) was marked out and the positions of 80 trees with diameter at breast height greater than $20 \mathrm{~mm}$ within each quadrat were mapped. In May and June 1990, two branches were randomly chosen at breast height on each of the 80 mapped trees at each site, and the last 2 years of needles were removed to facilitate inoculation. The bark of 1- and 2-year-old tissue on each branch was surface sterilised with ethanol, and a circle of bark $7 \mathrm{~mm}$ in diameter was removed with a cork borer from both the 1and 2-year-old portion of the shoots.

A $7 \mathrm{~mm}$ disk of inoculum was cut from the appropriate mixture and secured with Parafilm ${ }^{\mathrm{TM}}$ in the recess left after the bark removal. One branch was inoculated with a mixture containing $C$. sororia isolates from the same population possessing the Got $t^{F}$ allele, the other branch with a mixture containing isolates from the same population possessing the Got $^{S}$ allele. A total of 320 artificial inoculations were made at each of the three sites.

Each inoculated branch was marked with an aluminium tag signifying the inoculation mixture applied. In September 1990, the Parafilm ${ }^{\mathrm{TM}}$ was removed from each inoculation site. In June 1991, the 1- and 2-year-old inoculated shoots were harvested separately from all 80 trees at each site. Prior to lesion analysis the shoots were wrapped in aluminium foil and stored frozen at $-20^{\circ} \mathrm{C}$.

\section{Assessment of infection}

Each inoculation was scored for the presence/absence of tissue infection and the presence/absence of pycnidia on the canker surface. In order to quantify the extent of tissue invasion following inoculation, all lesions were cut longitudinally and the length of blackened phloem and xylem tissue resulting from $C$. sororia colonisation was measured.

\section{Final composition of pathogen genotypes derived from mixed inocula}

To determine the composition of genotypes surviving and reproducing asexually 1 year after inoculation, a single pycnidium was removed at random from each lesion possessing pycnidia. The pycnidium was crushed in sterile distilled water and the asexually produced macroconidial suspension thus generated was spread on MEA. After germination a single spore isolate was removed from the plate, grown in LCM and scored for its GOT isozyme genotype to determine its population of origin. 
Selection in a forest pathogen RA Ennos and KC McConnell

196

Comparison of genotype frequencies in pycnidia and wood

In order to establish whether the genotypic composition of isolates producing pycnidia reflected the genotypic composition of $C$. sororia present as vegetative mycelium in the blackened wood, a sliver of infected tissue was removed aseptically from each successful branch tip inoculation made with inoculum $\mathrm{I}_{2}$ at Glen Affric. C. sororia was re-isolated from this wood sample on MEA, then grown up in LCM and scored for its genotype at the GOT locus. The frequencies of Got genotypes in these re-isolations from wood were compared with those found for pycnidial re-isolations from the same samples.

Statistical analysis of factors affecting inoculum success Each mixture had been inoculated on 80 trees within each of two populations, and on tissue of two ages within each tree. Measurements of infection (present or absent), length of infection (in $\mathrm{mm}$ ) and pycnidia production (present or absent) were recorded. To determine the effect of the host population and the position of infection on inoculum success the data were analysed as a split plot design with trees within populations representing plots, and the factors being population, position of inoculation and their interaction.

Statistical analysis was by general linear modelling using the GLIM package (Francis et al, 1993; Crawley, 1993). For binary data (presence/absence of infection and pycnidia) a binomial error and logit link function were used, while for data on infection length the normal error and identity link function were employed.

\section{Statistical analysis of inoculum component success and} selective value

A general linear modelling approach was also used to determine whether there were any significant effects of the factors 'population' and 'position of inoculation' on the success of component genotypes coming from the two genetically marked populations in each inoculation mix. To analyse these data on counts of individual isolates the Poisson error and log link options were employed in GLIM. The influence of the factors (population, position and population $\times$ position) on the frequency of component genotypes in the sample of re-isolates was assessed by looking at the significance of the interactions between genotype and these factors (Crawley, 1993).

Where a factor was shown to have no significant interaction with genotype, data were pooled over this factor for later analysis. $\chi^{2}$ tests were then used to assess the significance of differences between marker genotype frequencies scored in the original isolate mixture (census 0 ) and in appropriately pooled samples of isolates recovered from pycnidia (census 1). This analysis indicated whether significant changes in the proportion of isolates derived from different populations had occurred during the year following inoculation of a particular mix.

If the relative selective value of the isolates from the more successful population in an inoculum mixture is set at 1.0, the relative selective value of isolates from the less successful population $(\mathrm{W})$ can be estimated as:

$$
W=q_{1} p_{0} / q_{0} p_{1}
$$

where $q_{0}$ and $q_{1}$ are the frequencies, at censuses 0 and 1 , respectively, of the inoculum component that decreases in frequency, and $p_{0}$ and $p_{1}$ are the frequencies, at censuses 0 and 1, respectively, of the inoculum component that increases in frequency (Ennos and McConnell, 1995).

\section{Results}

\section{Success and general effects of inoculations}

Over all sites, $74 \%$ of inoculations led to canker formation. The mean length of infected tissue in cankers was $11.05 \mathrm{~mm}$ after 1 year and the mean frequency of inoculations that lead to formation of pycnidia after 1 year was $64 \%$.

\section{Effects of inoculation position and host population on infection success}

Each of the three inoculum mixtures was used to infect two P. sylvestris populations. In any one population, each mixture was inoculated at two positions on a single branch on all 80 mapped trees. Figure 1 illustrates the variation in the performance of the three inocula with respect to host population and inoculation position. Performance is measured in terms of frequency of infection (Figure 1a), length of lesions (Figure 1b), and frequency of pycnidia production (Figure 1c).

For all three inocula, the frequency of infection was affected by both host population and inoculation position, as shown by the significance of the host population $\times$ infection position interaction terms (Table 1). At LM, the frequency of infection did not differ between infection positions, while at $\mathrm{GA}$ and $\mathrm{AB}$, the infection frequency was lower on 2 year than on 1-year tissue. This was most marked at $A B$ (Figure 1a). Differences in infection frequency were also highly significant among individual trees within populations $(P<0.001$, Table 1$)$.

Lesion length was also influenced significantly by both host population and position of inoculation for all three inocula. This was shown by significant interaction between these factors for mixes $I_{1}$ and $I_{2}$, and by significant main effects for both factors in the case of mix $I_{3}$. (Table 2, Figure $1 b$ ). In population LM, lesion length tended to be shorter for inoculations on 1-year-old tissue, while in populations $\mathrm{GA}$ and $\mathrm{AB}$, lesion length was shorter when inoculations were on 2-year-old tissue (Figure $1 b$ ). There was also highly significant variation in lesion length among individual trees within populations for all three inocula (Table 2).

In terms of frequency of pycnidia production following inoculation, both host population and position of inoculation again had significant effects as a result of interactions between these factors for inocula $\mathrm{I}_{1}$ and $\mathrm{I}_{3}$, and because of significant main effects for inoculum $\mathrm{I}_{2}$ (Table 3). Frequency of pycnidia production tended to be lower for inoculations on 2-year-old tissue, and this was most marked for the AB population (Figure 1c). As was the case for the other measures of inoculation behaviour, variation in frequency of pycnidia production among individual trees within populations was very highly significant (Table 3).

\section{Frequencies of marked genotypes in initial inocula and} recovered from pycnidia

Table 4 shows the number of $C$. sororia isolates of each genotype scored in the initial inocula used to 
a
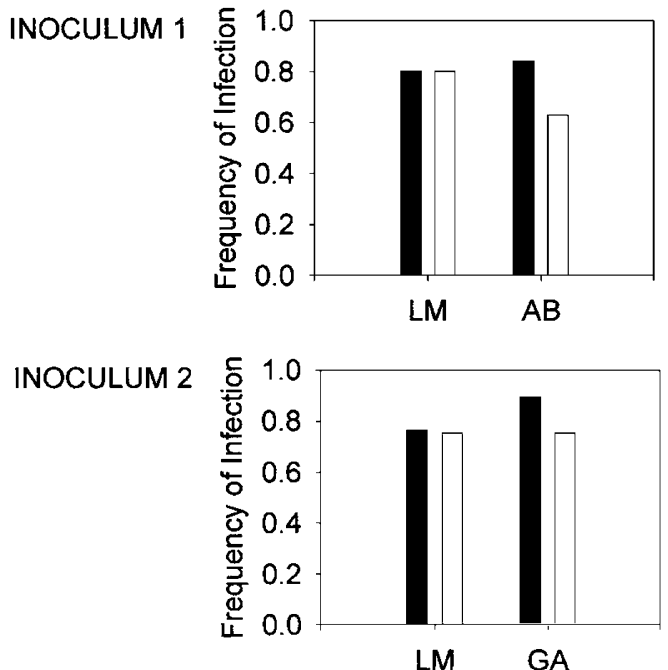

INOCULUM 3

year 1 year 2

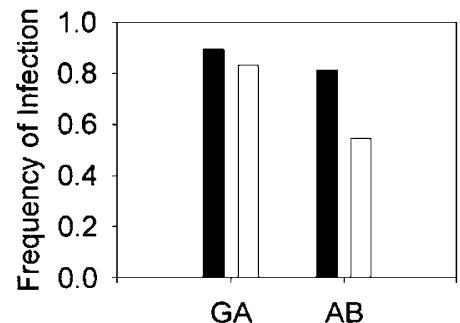

b

INOCULUM 1

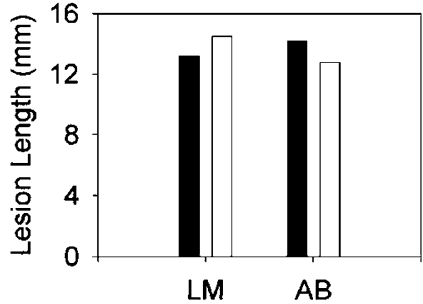

INOCULUM 2

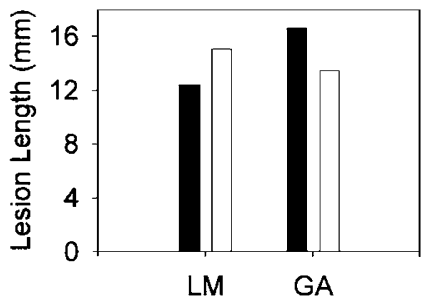

INOCULUM 3

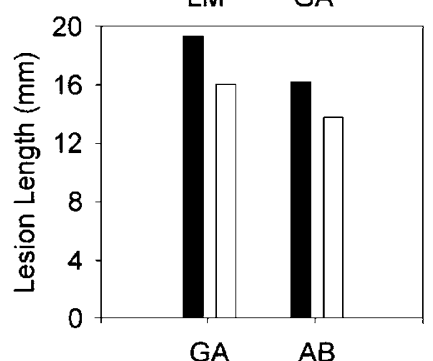

year 1

year 2

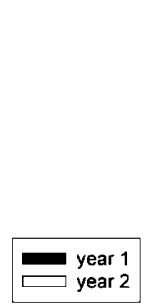

C

INOCULUM 1

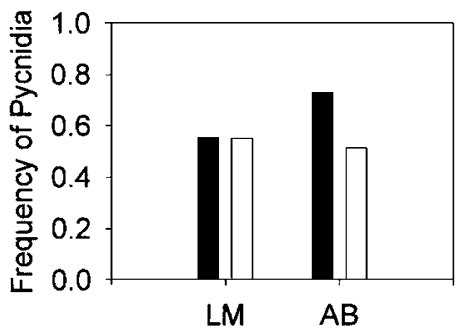

INOCULUM 2
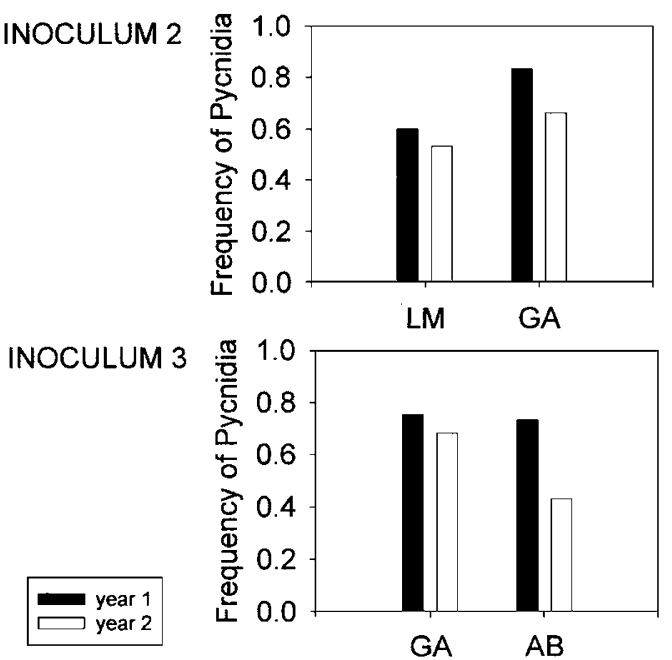

Figure 1 Success of Crumenulopsis sororia inocula 1,2 and 3 when inoculated at sites LM, GA and AB on 1- and 2-year old branch tissue of $P$. sylvestris. Success of inocula is measured as frequency of infection (a), lesion length (b) and frequency of pycnidia production (c).

set up the experiment and in the samples recovered from pycnidia after 1 year at each site and on each tissue. There is no significant deviation from a 1:1 ratio of $\operatorname{Got}^{F}$ and Got ${ }^{S}$ genotypes in any of the initial inocula $\left(\chi_{(1)}^{2}=0.007,0.057\right.$ and 2.279 for $\mathrm{I}_{1}, \mathrm{I}_{2}$ and $\mathrm{I}_{3}$, respectively). 
Table 1 General linear model analysis of the effects of factors host population, trees within populations and inoculation position on the frequency of infection following artificial inoculation of Pinus sylvestris populations with three inoculum mixes of Crumenulopsis sororia

\begin{tabular}{|c|c|c|c|c|c|c|c|}
\hline \multirow[t]{2}{*}{ Factor } & \multirow[t]{2}{*}{$d f$} & \multicolumn{2}{|c|}{ Inoculum $I_{1}$} & \multicolumn{2}{|c|}{ Inoculum $\mathrm{I}_{2}$} & \multicolumn{2}{|c|}{ Inoculum $I_{3}$} \\
\hline & & $\chi^{2}$ & $\mathrm{~F}_{1,158}$ & $\chi^{2}$ & $\mathrm{~F}_{1,158}$ & $\chi^{2}$ & $\mathrm{~F}_{1,158}$ \\
\hline Host population (P) & 1 & 2.1 & 1.3 & 1.9 & 1.2 & 15.0 & $10.7^{* *}$ \\
\hline Trees/population (T) & 158 & $254.9^{* * *}$ & & $240.4^{* * *}$ & & $219.9^{* * *}$ & \\
\hline Inoculation position (I) & 1 & $18.4^{* * *}$ & & $9.2^{* *}$ & & $38.7^{* * *}$ & \\
\hline $\mathrm{P} \times \mathrm{I}$ & 1 & $13.4^{* * *}$ & & $4.5^{*}$ & & $4.7^{*}$ & \\
\hline
\end{tabular}

Owing to the presence of heterogeneity among trees within populations, the significance of the population effect is determined by testing the 'between population' variation against the 'tree within population' variation using an $F$ test. ${ }^{*} P<0.05 ;{ }^{* *} P<0.01 ;{ }^{* * *} P<0.001$.

Table 2 General linear model analysis of the effects of factors host population, trees within population and inoculation position on the length of lesion produced following artificial inoculation of Pinus sylvestris populations with three inocula of Crumenulopsis sororia

\begin{tabular}{lrrc}
\hline Factor & $d f$ & $M S$ & $\mathrm{~F}$ \\
\hline (a) Inoculum $I_{1}$ & & & \\
Host population (P) & 1 & 4.0 & 0.1 \\
Trees/population (T) & 136 & 50.3 & $3.1^{* * *}$ \\
Inoculation position (I) & 1 & 0.5 & 0.0 \\
$\mathrm{P} \times \mathrm{I}$ & 1 & 100.1 & $6.1^{*}$ \\
Residual & 99 & 16.3 & \\
& & & \\
(b) Inoculum $I_{2}$ & & 114.8 & 1.9 \\
Host population (P) & 1 & 59.2 & $1.9^{*}$ \\
Trees/population (T) & 137 & 2.1 & 0.1 \\
Inoculation position (I) & 1 & 606.1 & $19.3^{* *}$ \\
P $\times$ I & 1 & 31.4 & \\
Residual & 98 & & \\
& & 379.0 & $5.5^{*}$ \\
(c) Inoculum $I_{3}$ & 1 & 68.9 & $2.3^{* * *}$ \\
Host population (P) & 138 & 1.3 & 0.1 \\
Trees/population (T) & 1 & 562.9 & \\
Inoculation position (I) & 1 & 29.6 & \\
P $\times$ I & 92 & & \\
Residual & & & \\
\hline
\end{tabular}

${ }^{*} P<0.05 ;{ }^{* *} P<0.01 ; * * * P<0.001$.

The effects of host population and inoculation position on the frequencies of the genetically marked components recovered from the pycnidial sample are analysed in Table 5. For all three mixtures the frequency of genetically marked components in the pycnidia sample varies with inoculation position $(P<0.05)$. On the other hand they are neither influenced by the population on which inoculations were made, nor by the interaction between population and position of inoculation. These results indicate that when analysing changes in frequency of isolate components between the initial inoculum and the sample taken from pycnidia, it is legitimate to combine the pycnidial samples over host populations. However, separate analyses should be conducted for inoculations made on 1- and 2-year-old tissue.

Table 6 shows the results of $\chi^{2}$ analysis to test for differences in frequencies of isolate components derived from initial inoculum mixes and corresponding pycnidial samples taken from cankers. The frequency of genetically marked $C$. sororia isolates derived from different populations within each mixture differs significantly between the initial and the pycnidial samples for all three mixtures inoculated on 2-year-old tissue $\left(P<0.001\right.$ for mixtures $\mathrm{I}_{1}$ and $\mathrm{I}_{2}, P<0.05$ for mixture $\left.\mathrm{I}_{3}\right)$. In the case of mixture $\mathrm{I}_{2}$ on 1-year tissue, there is also a significant difference between genetic composition of initial and pycnidial samples $(P<0.001$, Table 6$)$. In each of these cases, significant differences in selective value are evident between the $C$. sororia isolates derived from the two natural populations included in the inoculum mixture.

Figure 2 shows the relative selective values of the component $C$. sororia populations included in the three mixtures calculated from the change in frequency of these components between the initial and pycnidial samples. Some of the estimated selective values, for instance 0.14 and 0.36 for GA relative to LM isolates in mix $I_{2}$, are very low. This implies the action of very strong selection. In the mixtures where they are included, LM isolates show higher selective values than their counterparts from the other two populations. Where GA

Table 3 General linear model analysis of the effects of factors like host population, trees within populations and inoculation position on the frequency of pycnidia production following artificial inoculation of Pinus sylvestris populations with three inocula of Crumenulopsis sororia

\begin{tabular}{|c|c|c|c|c|c|c|c|}
\hline \multirow[t]{2}{*}{ Factor } & \multirow[t]{2}{*}{$d f$} & \multicolumn{2}{|c|}{ Inoculum $I_{1}$} & \multicolumn{2}{|c|}{ Inoculum $\mathrm{I}_{2}$} & \multicolumn{2}{|c|}{ Inoculum $\mathrm{I}_{3}$} \\
\hline & & $\chi^{2}$ & $\mathrm{~F}_{1,158}$ & $\chi^{2}$ & $\mathrm{~F}_{1,158}$ & $\chi^{2}$ & $\mathrm{~F}_{1,158}$ \\
\hline Population (P) & 1 & 1.6 & 0.8 & 11.7 & $6.8^{* *}$ & 6.6 & $3.94^{*}$ \\
\hline Trees/population (T) & 158 & $319.2^{* * *}$ & & $271.1^{* * *}$ & & $266.0^{* * *}$ & \\
\hline Inoculation position (I) & 1 & $14.5^{* * *}$ & & $15.8^{* * *}$ & & $36.9^{* * *}$ & \\
\hline $\mathrm{P} \times \mathrm{I}$ & 1 & $13.6^{* * *}$ & & 2.8 & & $10.6^{* * *}$ & \\
\hline
\end{tabular}

Owing to the presence of heterogeneity among trees within populations, the significance of the population effect is determined by testing 'between population' variation against the 'tree within population' variation using an $F$ test. ${ }^{*} P<0.05$; ${ }^{* *} P<0.01$; ${ }^{* * *} P<0.001$. 
Table 4 Numbers of Got $^{F}$ and Got ${ }^{S}$ genotypes of Crumenulopsis sororia scored in initial inocula and in re-isolations from pycnidia formed 1 year after inoculation on different host populations (LM, $\mathrm{AB}$ and $\mathrm{GA}$ ) and host tissues (1 and 2 year)

\begin{tabular}{llcc}
\hline $\begin{array}{l}\text { Inoculum } \\
\text { mixture }\end{array}$ & Sample scored & Got $^{\mathrm{F}}$ re-isolated & Got $^{\mathrm{S}}$ re-isolated \\
\hline $\mathrm{I}_{1}$ & & & \\
& Initial inoculum & 76 & 75 \\
& LM 1 year & 23 & 20 \\
& LM 2 year & 30 & 13 \\
& AB 1 year & 33 & 29 \\
& AB 2 year & 21 & 10 \\
$\mathrm{I}_{2}$ & Initial inoculum & 80 & 77 \\
& LM 1 year & 6 & 44 \\
& LM 2 year & 12 & 29 \\
& GA 1 year & 7 & 45 \\
& GA 2 year & 10 & 30 \\
$\mathrm{I}_{3}$ & Initial inoculum & 36 & 50 \\
& AB 1 year & 18 & 29 \\
& AB 2 year & 9 & 20 \\
& GA 1 year & 23 & 28 \\
& GA 2 year & 8 & 31 \\
\hline
\end{tabular}

Table 5 General linear model analysis of the effects of host population and position of inoculation on the frequency of component genotypes found in the pycnidial population of Crumenulopsis sororia developed 1 year after inoculation of three different inoculum mixes, each on two Pinus sylvestris populations

Inoculum $I_{1} \quad$ Inoculum $I_{2} \quad$ Inoculum $I_{3}$

\begin{tabular}{lcccc}
\hline $\begin{array}{l}\text { Interaction } \\
\text { Genotype } \times \text { host }\end{array}$ & $d f$ & $\chi^{2}$ & $\chi^{2}$ & $\chi^{2}$ \\
$\begin{array}{l}\text { population }(\mathrm{P}) \\
\begin{array}{l}\text { Genotype } \times \text { inoculation } \\
\text { position }(\mathrm{I})\end{array}\end{array}$ & 1 & 0.24 & 0.05 & 0.02 \\
\begin{tabular}{l} 
Genotype $\times \mathrm{P} \times \mathrm{I}$ \\
\hline
\end{tabular} & 1 & 0.02 & $6.02^{*}$ & $5.10^{*}$ \\
\hline
\end{tabular}

${ }^{*} P<0.05$

Table 6 Results of $\chi^{2}$ tests with one degree of freedom comparing frequencies of genetically marked Crumenulopsis sororia isolates from two populations in the original inoculation mixtures with their frequencies in the pycnidial population 1 year after inoculation

\begin{tabular}{lcc}
\hline Inoculam & 1-year tissue & 2-year tissue \\
\hline $\mathrm{I}_{1}$ & $0.22 \mathrm{NS}$ & $6.98^{* * * *}$ \\
$\mathrm{I}_{2}$ & $39.22^{* * *}$ & $12.35^{* * *}$ \\
$\mathrm{I}_{3}$ & $0.00 \mathrm{NS}$ & $4.78^{*}$ \\
\hline
\end{tabular}

Analyses are conducted separately for the two different inoculation positions because of heterogeneity of the results over inoculation position (Table 5); NS, nonsignificant ${ }^{*} P<0.05$; ${ }^{* * *} P<0.001$.

and $\mathrm{AB}$ are in competition, isolates from GA are of higher selective value, at least on 2-year-old host tissue.

Frequency of genotypes in pycnidia and infected wood For inoculum $\mathrm{I}_{2}$ on 1-year tissue at GA, the frequency of genetically marked components isolated from pycnidia $(n=52)$ was compared with their frequency in isolations from infected wood $(n=73)$. There was no significant
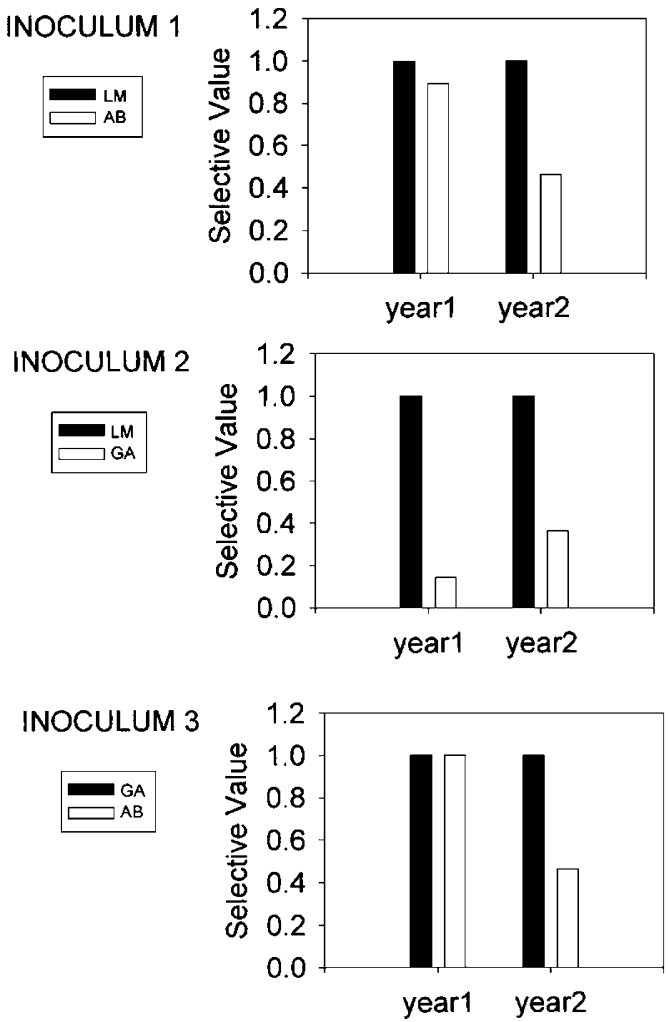

Figure 2 Relative selective values of Crumenulopsis sororia genotypes from populations LM, GA and AB in inoculum mixes 1, 2 and 3 when inoculated on 1- and 2-year old branch tissue of $P$. sylvestris.

difference between the two samples in terms of the frequencies of components in the mixture as determined by scoring the GOT marker allele $\left(\chi_{(1)}^{2}=0.064 \mathrm{NS}\right)$.

\section{Discussion}

The first conclusion that can be drawn from this experiment is that the host environment occupied by C. sororia is very heterogeneous. All three measures of the performance of pathogens are influenced by host population, variation among trees within populations and age of tissue infected. An unexpected result is that in many cases the main effect of host population on pathogen performance is not significant, but the interaction between host population and inoculation position is substantial. There is variation between populations because the relative resistance of 1- and 2-year-old tissue is not constant, but depends on the host population in which it is measured. This result implies that the expression of $C$. sororia resistance in different tissues varies among populations of $P$. sylvestris. It also indicates that the scale at which host heterogeneity is perceived by the pathogen is very small. There can be very important environmental heterogeneity within a single branch on the same tree.

This impression of the importance of small-scale host heterogeneity on pathogen performance is reinforced by the assessment of the selective value of genotypes in mixtures. There are large differences in the selective value of pathogens derived from different pinewoods. These differences are not influenced by the host population on which the isolates are grown. However, they are 
affected by the age of the tissue on which the isolates are competing. In two out of three cases, the difference in relative selective value of the isolates is greater on 2-year wood than on 1-year wood. Once again small-scale differences within a host are more important in terms of pathogen performance than are regional scale differences among host populations.

The second major conclusion that can be drawn from these experiments is that there are large differences in selective value between the $C$. sororia populations derived from different native populations. On average, isolates from LM have a much higher competitive ability on host tissue than those from GA or AB. Although these conclusions are based on the analysis of pycnidia production after 1 year, the congruence between reisolations from pycnidia and infected wood suggest that this reflects superiority competitive ability of LM isolates during invasion of host tissue.

Previous studies of selectively important variation in C. sororia have failed to detect genetic differences among populations from $A B, G A$ and $L M$. In an analysis of genetic variation for tolerance of host monoterpenes very little, if any, variation was attributable to differences among populations (Ennos and Swales, 1991b). On the other hand large differences in monoterpene tolerance were found among trees within populations. One explanation of these results was that for $C$. sororia, host differences at a small scale (among trees within populations) are more important in terms of selection than host differences at a regional scale (among pinewood populations).

The present results indicate that although host heterogeneity at a small scale is indeed important for selection in C. sororia, genetic differences influencing selective value of $C$. sororia have evolved over a regional scale. This regional scale differentiation has developed despite the high dispersal ability of $C$. sororia. This dispersal ability is demonstrated both by its ability to colonise remote but stressed populations of pines and by a low value of population genetic differentiation for allozyme markers (Ennos and Swales, 1991a).

The final conclusion that can be drawn from this work is that although genetic differences in competitive ability have been detected among $C$. sororia populations, there is no pattern of superior fitness of local pathogens. The relative competitive abilities of the $C$. sororia populations in mixture remain the same, irrespective of the host populations on which they are growing.

This result conflicts with the predictions of recent models developed to investigate the coevolution of metapopulations of hosts and pathogens at a regional scale (Gandon et al, 1996; Kaltz and Shykoff, 1998). Two important assumptions of these models are that matching of alleles in pathogens and hosts is required for infection and that the effect of the pathogen on host fitness is substantial. Under these conditions local adaptation of the pathogen (greater virulence on local hosts) is predicted so long as pathogen dispersal exceeds host dispersal (the situation in C. sororia and P. sylvestris). Limited evidence from a number of systems tends to support these predictions (Kaltz and Shykoff, 1998; Kaltz et al, 1999).

Lack of the anticipated pattern of local adaptation in $C$. sororia may be related to the nature of the host-pathogen interaction involved. C. sororia is only one of the many pathogens attacking $P$. sylvestris, and its effects on host fitness are relatively small. It is also unlikely that matching of host and pathogen genes is required for infection, as assumed by models based on gene-for-gene systems. It is more probable that the success of pathogens is determined by their quantitative levels of aggressiveness. Different levels of $C$. sororia aggressiveness could evolve in the three pinewood sites in response to locally varying factors such as pathogen transmission probability and degree of host stress (and hence host resistance) (Read, 1994; Hochberg and van Baalen, 1998). In mixture the outcome of competition between pathogen populations would be unaffected by the host population on which they competed, and would merely depend on the relative levels of pathogen aggressiveness evolved in the three different pinewoods. Independent measures of the aggressiveness of $C$. sororia isolates from different populations inoculated individually on host trees would be needed to test this hypothesis.

Although the experiments reported here do not provide a simple picture of pathogen evolution in response to quantitative host resistance, they do indicate a number of features that need to be incorporated into future thinking. The first is that for a pathogen such as C. sororia significant variation in host resistance occurs at many levels; among populations, among individuals within populations and within individuals. Pathogen evolution occurs in a highly heterogeneous environment. The second is that the selective value of a $C$. sororia genotype is strongly dependent upon small-scale variation in the host tissue on which it is growing.

In the future it will be important to determine whether similar heterogeneity in host environment is perceived by other pathogens encountering quantitative host resistance. It will also be essential to determine whether there are significant trade-offs in performance of such pathogens in different host environments. For instance, do genotypes that compete well in stressed hosts compete poorly in well-defended hosts? Only when such questions have been answered will it be possible to understand pathogen evolution in the many situations where gene-for-gene interactions contribute little to variation in pathogen and host fitness.

\section{Acknowledgements}

This research was funded by a grant from the Natural Environment Research Council to RAE.

\section{References}

Batko S, Pawsey RG (1964). Stem canker of pine caused by Crumenula sororia. Trans Br Mycol Soc 47: 257-261.

Burdon JJ, Jarosz AM (1991). Host-pathogen interactions in natural populations of Linum marginale and Melampsora lini: I. Patterns of resistance and racial variation in a large host population. Evolution 45: 205-217.

Burdon JJ, Thrall PH (1999). Spatial and temporal patterns in coevolving plant and pathogen associations. Am Nat 153: S15-S33.

Crawley MJ (1993). GLIM for Ecologists. Blackwell Science Ltd.: Oxford.

De Nooij MP, van Damme JMM (1988a). Variation in pathogenicity among and within populations of the fungus Phomopsis subordinaria. Evolution 42: 1166-1171. 
De Nooij MP, van Damme JMM (1988b). Variation in host susceptibility among and within populations of Plantago lanceolata L. infected with the fungus Phomopsis subordinaria. Oecologia 75: 535-538.

Ennos RA, McConnell KC (1995). Using genetic markers to measure natural selection in populations of fungi. Can J Bot 73: S302-S310.

Ennos RA, Swales KW (1987). Estimation of the mating system in a fungal pathogen Crumenulopsis sororia (Karst.) Groves using isozyme markers. Heredity 59: 423-430.

Ennos RA, Swales KW (1991a). Genetic variability and population structure in the canker pathogen Crumenulopsis sororia. Mycol Res 95: 521-525.

Ennos RA, Swales KW (1991b). Genetic variation in a fungal pathogen: response to host defensive chemicals. Evolution 45: 190-204.

Ennos RA, Sinclair WT, Perks MT (1997). Genetic insights into the evolution of Scots pine, Pinus sylvestris L., in Scotland. Bot I Scotl 49: 257-265.

Flor HH (1956). The complementary genic systems in flax and flax rust. Adv Genet 8: 29-54.

Francis B, Green M, Payne C (1993). The GLIM System: Release 4 Manual. Clarendon Press: Oxford.

Gandon S, Capowiez Y, Dubois Y, Michalakis Y (1996). Local adaptation and gene for gene coevolution in a metapopulation model. Proc R Soc Lond B 263: 1003-1009.

Hayes AJ, Manap Ahmad A (1975). The infection of Corsican pine by Crumenula sororia Karst. Forestry 48: 183-191.

Hochberg ME, van Baalen M. (1998). Antagonistic coevolution over productivity gradients. Am Nat 152: 620-634.

Jarosz AM, Davelos AL (1995). Effects of disease in wild populations and the evolution of pathogen aggressiveness. New Phytol 129: 371-387.
Kaltz O, Shykoff JA (1998). Local adaptation in host-parasite systems. Heredity 81: 361-370.

Kaltz O, Gandon S, Michalakis Y, Shykoff JA (1999). Local maladaptation in the anther-smut fungus Microbotryum violaceum to its host plant Silene latifolia: evidence from a cross-inoculation experiment. Evolution 53: 395-407.

Kolmer JA, Leonard KJ (1986). Genetic selection and adaptation of Cochliobolus heterostrophus to corn hosts with partial resistance. Phytopathology 76: 774-777.

Manion PD (1990). Tree Disease Concepts, 2nd edn. Prentice-Hall: London.

Parker MA (1994). Pathogens and sex in plants. Evol Ecol 8: 560 584.

Parlevliet JE (1989) Identification and evaluation of quantitative resistance. In: Leonard KJ, Fry WE (eds) Plant Disease Epidemiology, Vol. 2. Genetics, Resistance and Management, McGraw-Hill: New York. pp 215-248.

Read AF (1994). The evolution of virulence. Trends Microbiol 2: 73-76.

Schoenweiss DF (1975). Predisposition, stress and plant disease. Ann Rev Phytopathol 13: 193-211.

Schoenweiss DF (1981). The role of environmental stress in disease of woody plants. Plant Dis 65: 308-314.

Steven HM, Carlisle A (1959). The Native Pinewoods of Scotland. Oliver and Boyd: Edinburgh.

Thompson JN, Burdon JJ (1992). Gene-for-gene coevolution between plants and parasites. Nature 360: 121-125.

Thrall PH, Burdon JJ (1997). Host-pathogen dynamics in a metapopulation context; the evolutionary consequences of being spatial. J Ecol 85: 743-753. 